\title{
PROFESIONALISME TENAGA PENDIDIK DALAM MENINGKATKAN MUTU PENDIDIKAN
}

\author{
Yuli Anggraini \\ Email : ainianggraini2216@gmail.com
}

\begin{abstract}
ABSTRAK
Kualitas Pendidikan yang rendah dapat menyebabkan kualitas SDM menjadi rendah pula; semakin tinggi tingkat Pendidikan maka semakin tinggi pula kualits SDM yang nantinya sangat berpengaruh kepada cara nalar, berfikir, keluasan wawasan serta pengetahuan yang dimiliki. Hal ini bertujuan untuk mengethaui terkait profesionalisme, faktor-faktor yang mempengaruhi pendidik professional serta kompetensi pendidik profesional. Profesionalisme pendidik dapat tercermin pada proses pelaksanaan tugas yang ditandai dengan keahlian baik dalam hal materi yang disampaikan maupun strategi pembelajaran yang digunakan. Sosok profesionalisme seorang pendidik ditunjukkan dengan sikap bertanggung jawab dalam melaksanakan pengabdian. Sikap profesional ini hendaknya mampu menopang dan melaksanakan tanggung jawab sebagai pendidik kepada peserta didik, orang tua, masyarakat, bangsa negara, dan agamanya.
\end{abstract}

Kata kunci : profesionalisme

\section{LATAR BELAKANG}

Pendidikan merupakan suatu usaha yang sengaja direncanakan untuk mencapai tujuan yang telah ditetapkan. Pendidikan juga merupakan hal yang sangat berperan penting dalam kehidupan. Sebagaimana yang terdapat dalam Undang-Undang Dasar 1945, “...Mencerdaskan kehidupan bangsa....". Hal ini merupakan salah satu tujuan nasional yang ingin dicapai bangsa Indonesia.

Mutu Pendidikan juga sangat tergantung pada komponen-komponen yang terdapat dalam pendidikan, salah satu diantara komponen yang sangat mempengaruhi berhasil tidaknya pendidikan adalah tergantung dari kualitas tenaga pendidik. Pemerintah juga mengambil kebijakan dengan menerbitkan UU No.14 tahun 2005 tentang guru dan dosen, pada intinya meningkatkan kuliatas guru dan dosen. Guru sebagai tenaga profesional berarti pekerjaan guru hanya dilakukan oleh seseorang yang memiliki kualifikasi akademik, kompetensi, dan sertifikat pendidik sesuai dengan persyaratan untuk setiap jenis dan Pendidikan tertentu.

Oleh karena itu, komponen pendidik merupakan salah satu dalam kegiatan belajar mengajar, memiliki peran yang sangat menentukan keberhasilan pembelajaran. Melihat begitu pentingnya peran guru sebagai pendidik dalam proses Pendidikan dan sekaligus sebagai pihak yang bertanggungjawab dalam pelaksaan proses Pendidikan di sekolah, guru dituntut untuk memiliki jiwa profesionalisme yang tinggi.

Berdasarkan uraian diatas, permasalahan dalam tulisan ini adalah (1) Apa yang dimaksud dengan profesionalisme pendidik? (2) Apa yang dimaksud dengan mutu pendidikan? (3) Bagaimana upaya yang harus dilakukan untuk mencapai keprofesionalan seorang pendidik? Tujuan tulisan ini adalah (1) Untuk memahami tentang Profesionaisme pendidik. (2) Untuk memahami tentang mutu Pendidikan. (3) Untuk mengetahui upaya yang harus dilakukan untuk mencapai keprofesionalan seorang pendidik. 


\section{PEMBAHASAN}

\section{Apa itu Profesionalisme Pendidik?}

Berbicara tentang profesionalisme mencerminkan sikap seorang terhadap profesinya. Secara sederhana, profesionalisme dapat diartikan sebagai perilaku, cara, dan kualitas dari suatu profesi. Sehingga, seseorang dapat dikatakan profesional jika pekerjaannya memiliki ciri standar teknis atau etika suatu profesi.

Profesionalisme juga dapat diartikan sebagai suatu kemampuan dan keterampilan seseorang dalam melakukan pekerjaan menurut bidang keahlian dan tingkatan masing-masing.

Jadi, profesionalisme pendidik adalah kemampuan dan keahlian khusus seorang pendidik di bidangnya serta telah berpengalaman dalam mengajar sehingga ia mampu melakukan tugas dan fungsinya sebagai pendidik dengan kemampuan yang maksimal serta berkompeten sesuai dengan kriteria pendidik yang profesional.

Menurut (Sabandi, 2013) Pengembangan keprofesionalitas guru berkelanjutan merupakan hal yang penting untuk meningkatkan kualitas pembelajaran seiring dengan perkembangan ilmu pengetahuan, teknologi, serta sosial ekonomi, dan budaya masyarakat. Supervisor sebagai penanggung jawab keberhasilan penyelenggaraan pendidikan dapat dilakukan dengan berbagai pendekatan untuk meningkatkan keprofesionalitas guru, di antaranya teknik supervisi, budaya organisasi pembelajaran,dan kegiatan pelatihan.

\section{Tentang Mutu Pendidikan}

Menurut kamus besar Bahasa Indonesia, "Mutu adalah ukuran baik atau buruk suatu benda; kadar; atau derajat (kepandaian, kecerdasan dsb);kualitas.

Menurut (Paci, 2013) dalam bukunya, disebutkan bahwa "secara umum, mutu adalah gambaran dan karakteristik menyeluruh dari barang dan jasa yang menunjukkan kemampuannya dalam memuaskan kebutuhan yang diharapkan atau yang tersirat. Pada konteks pendidikan, pengertian mutu mencakup input, proses, dan output pendidikan.

Sedangkan, menurut Ensiklopedi Pendidikan Indonesia menjelaskan mengenai Pendidikan, yaitu sebagai proses membimbing manusia atau anak didik dari kegelapan, ketidaktahuan, kebodohan, dan kecerdasan pengetahuan.

Oleh karena itu, maka mutu pendidikan dapat disimpulkan sebagai standar ukuran yang ingin dicapai pada proses pendidikan melalui kegiatan bimbingan kepada peserta didik demi tercapainya tujuan hidup yang ingin dicapai.

\section{Upaya yang harus dilakukan untuk mencapai keprofesionalan seorang pendidik.}

Profesionalisme pendidik sebagai upaya peningkatan mutu pendidikan sangatlah penting. Menurut (Putri \& Imaniyati, 2017), sebagai guru atau pendidik yang professional seharusnya memiliki empat kompetensi, yaitu kompetensi pedagogic, kognitif, personality, dan social. Oleh karena itu, selain terampil mengajar, seorang guru juga memiliki pengetahuan bijak dan dapat bersosialisasi dengan baik. Profesi guru dan dosen merupakan bidang pekerjaan khusus yang memerlukan prinsip-prinsip profesional.

Maka, hal yang perlu dimiliki seorang pendidik yang profesional, yaitu :

1. Memiliki bakat, minat, panggilan jiwa, dan idealisme

2. Memiliki komitmen untuk meningkatkan mutu pendidikan, keimanan, ketakwaan, serta akhlak mulia

3. Memiliki kualifikasi akademik dan latar pendidikan sesuai dengan bidang tugas

4. Memiliki kompetensi yang diperlukan sesuai dengan bidang tugas

5. Memiliki tanggungjawab atas keprofesionalan

6. Memperoleh penghasilan yang ditentukan sesuai dengan prestasi kerja

7. Memiliki kesempatan untuk mengembangkan keprofesionalan secara berkelanjutan dengan belajar sepanjang hayat 
8. Memiliki jaminan perlindungan hukum dalam melaksanakan tugas keprofesionalan

9. Memiliki organisasi profesi yang mempunyai kewenangan yang mengatur hal-hal yang berkaitan dengan tugas keprofesionalan guru (Undang-Undang Dasar tentang Guru dan Dosen, 2006:7).

Sedangkan menurut (Pendidikan, 2016), untuk lebih mendukung tercapainya peningkatan kemampuan profesionalisme guru, pemerintah dalam hal ini Depdiknas senantiasa secara priodik memfasilitasi kegiatan melalui :

1. Peningkatan kualitas guru melalui penyelenggaraan penyetaraan disetiap jenjang Pendidikan

2. Peningkatan kemampuan profesionaisme guru melalui kegiatan penataran/pelatihan bekerja sama dengan Lembaga-lembaga penalaran atau diklat

3. Memotivasi pengembangan kelompok kerja guru melalui PKG, PSB SPKG, PPPG dan sebagainya

4. Penyesuaian penataran/pemerataan jumlah guru dalam berbagai jumlah studi/mata pelajaran guna memenuhi kebutuhan kurikulum

5. Mensubsidi bantuan tenaga guru serta melakukan pembinaan mutu guru pada setiap sekolah khususnya sekolah swasta

6. Melakukan pembinaan karir guru sesuai jabatan fugsional guru

7. Secara periodik berusaha meningkatkan guru melalui berbagai cara atau terbosan

Upaya-upaya peningkatan profesionalitas guru ini harus dilakukan secara sistematis, maksudnya adalah direncanakan dengan matang, dilaksanakan secara taat asas dan dievaluasi secara objektif. Seharusnya yang melakukan upaya peningkatan pofesionalisme guru ini tidak hanya para kepala sekolah maupun pemerintah tetapi yang paling menentukan yakni guru yang bersangkutan. Meskipun telah diikutkan pelatihan atau telah disupervisi tanpa disertai kemauan dan kesadaran dari guru yang bersangkutan, oleh karena itu semua kegiatan yang dilakukan akan sia-sia.

\section{PENUTUP}

\section{Kesimpulan}

Berdasarkan pembahasan di atas disimpulkan bahwa kualitas proses belajar mengajar (KBM) sangat dipengaruhi oleh kualitas dari seorang pendidik. Oleh karena itu, sumber daya guru perlu tumbuh dan berkembang secara terus-menerus agar dapat mencapai fungsinya secara professional.

Profesionalisme pendidik juga sangat penting dalam peningkatan mutu Pendidikan, sebab seorang guru sebagai pendidik merupakan salah satu komponen yang sangat penting dalam proses pembelajaran. Apabila pendidik dapat melaksanakan tugasnya secara profesional, maka kualitas peserta didik juga akan baik. Setiap pendidik juga harus tau bagaimana kriteria pendidik yang profesional, karena dengan pengetahuan tersebut pendidik dapat menyesuaikan keadaan yang ada pada dirinya, artinya jika pendidik tersebut merasa bahwa dirinya kurang profesional maka harapannya ia akan berusaha untuk meningkatkan keprofesionalan pada dirinya. Hal ini sangat penting demi terwujudnya sumber daya yang berkualitas. 


\section{Saran}

Sebagai seseorang yang peduli terhadap pendidikan, sebaiknya kita selalu berusaha untuk meningkatkan mutu pendidikan tersebut melalui berbagai hal. Para pendidik hendaknya selalu berupaya untuk meningkatkan kualitas diri agar dapat menjadi pendidik yang profesional. Pada pendidik hendaknya tidak boleh terlalu puas dengan kemampuan yang telah dimiliki, namun harus senantiasa intropeksi dan berusaha memperbaiki diri.

\section{DAFTAR PUSTAKA}

Paci, P. T. (2013). Manajemen pengembangan mutu guru. 203-215.

Pendidikan, S. N. (2016). Kunci: LPTK, Guru Pembelajar, Profesional Guru. (2015), 97-104.

Putri, A. D. K., \& Imaniyati, N. (2017). Pengembangan Profesi Guru Dalam Meningkatkan Kinerja Guru. Jurnal Pendidikan Manajemen Perkantoran, 1(1), 94-103. Retrieved from http://ejournal.upi.edu/index.php/jpmanper/article/view/8109

Sabandi, A. (2013). Supervisi Pendidikan Untuk Pengembangan Profesionalitas Guru Berkelanjutan. Jurnal Ilmiah Ilmu Pendidikan, XIII(2), 1-9. 